$03,12,19$

\title{
Влияние температуры на размер частиц и рекристаллизацию нанопорошков сульфида серебра
}

\author{
() С.И. Садовников, А.И. Гусев \\ Институт химии твердого тела УрО РАН, \\ Екатеринбург, Россия \\ ฯ E-mail: gusev@ihim.uran.ru \\ (Поступила в Редакцию 5 декабря 2017 г. \\ В окончательной редакции 6 февраля 2018 г.)
}

\begin{abstract}
Изучена рекристаллизация и определена область термической стабильности размера наночастиц сульфида серебра $\mathrm{Ag}_{2} \mathrm{~S}$. Нанопорошки $\mathrm{Ag}_{2} \mathrm{~S}$ с размером частиц 45-50 nm получены химическим осаждением из водных растворов. Для изучения термической стабильности размера наночастиц $\mathrm{Ag}_{2} \mathrm{~S}$ нанокристаллические порошки отжигали в вакууме 0.01 Ра при нагреве от комнатной температуры до $493 \mathrm{~K}$ и в аргоне при 623 К. Отжиг вплоть до температуры $453 \mathrm{~K}$ приводит к незначительному росту наночастиц и отжигу микронапряжений, что позволяет считать этот диапазон температур областью термической стабильности наносостояния сульфида серебра. Диапазон температур от 450 до $900 \mathrm{~K}$, в котором размер частиц увеличивается в 3-6 раз, соответствует температуре собирательной рекристаллизации нанопорошка сульфида серебра.
\end{abstract}

DOI: 10.21883/FTT.2018.07.46113.341

\section{1. Введение}

Несмотря на активное изучение наноструктурированных полупроводниковых сульфидов, в литературе почти нет сведений об изменении размера их частиц (зерен) с температурой и рекристаллизации. Можно упомянуть лишь работу [1] по рекристаллизации пленок сульфида кадмия, в которой изменение размера зерен не обсуждалось, и работу [2] по рекристаллизации в нанопленках сульфида свинца,

Спецификой крупнокристаллического сульфида серебра является то, что при нагреве на воздухе он не окисляется до оксида и сульфата металла, как другие сульфиды, а разлагается с выделением металлического серебра и серы, окисляющейся до газообразного оксида $\mathrm{SO}_{2}$. Это характерно и для наноструктурированного сульфида серебра.

Основой современной электронной техники являются полупроводники на основе кремния и германия. Максимальная рабочая температура германиевых приборов не превышает $323-330 \mathrm{~K}$, для кремниевых приборов она возрастает до 400-430 К. Кремний лучше сохраняет стабильность работы при высоких температурах, однако повышение производительности интегральных схем, достигаемое путем наращивания рабочей тактовой частоты и увеличения количества транзисторов, при дальнейшем использовании кремния $\mathrm{Si}$ и других распространенных полупроводников становится все более сложной и дорогостоящей задачей. Дело в том, что по мере повышения тактовой частоты тепловыделение транзисторов усиливается по экспоненте. Поэтому важной задачей является определение областей термической стабильности полупроводниковых соединений и материалов, потенциально пригодных для работы при повышенной температуре. Одним из таких материалов является наноструктурированный сульфид серебра [3-5].
Потенциальное применение наноструктурированного сульфида серебра наиболее перспективно в микро- и наноэлектронике, где в энергонезависимых устройствах памяти и резистивных переключателях используются гетеронаноструктуры $\mathrm{Ag}_{2} \mathrm{~S} / \mathrm{Ag}$. Их действие основано на восстановлении катионов $\mathrm{Ag}^{+}$сульфида серебра до атомов металлического серебра $\mathrm{Ag}$, превращении акантита $\alpha-\mathrm{Ag}_{2} \mathrm{~S}$ в аргентит $\beta-\mathrm{Ag}_{2} \mathrm{~S}$ и возникновении проводящего канала из серебра $\mathrm{Ag}$ и аргентита $\beta-\mathrm{Ag}_{2} \mathrm{~S}$ [6-8]. Гибридные гетеронаноструктуры $\mathrm{Ag}_{2} \mathrm{~S} / \mathrm{Ag}$ обнаруживают повышенную эффективность в фотокатализе [9].

Стабильная работа микроэлектронных устройств и фотокатализаторов, элементом которых служит наноструктурированный сульфид серебра, непосредственно зависит от термической стабильности размеров наночастиц $\mathrm{Ag}_{2} \mathrm{~S}$. Однако в литературе сведения о термической стабильности наночастиц $\mathrm{Ag}_{2} \mathrm{~S}$ практически отсутствуют.

В настоящей работе обсуждается влияние температуры на размер частиц нанокристаллических порошков сульфида серебра и их рекристаллизацию. Благодаря высокоразвитой поверхности нанопорошки при хранении на воздухе адсорбируют кислород и атмосферную влагу, вследствие чего их нагрев даже в защитной атмосфере или вакууме помимо роста наночастиц может сопровождаться частичной диссоциацией, окислением серы и изменением фазового состава нанопорошка.

\section{2. Образцы и экспериментальные методы}

Нанокристаллический порошок сульфида серебра со средним размером частиц $45-55 \mathrm{~nm}$ получали гидро- 


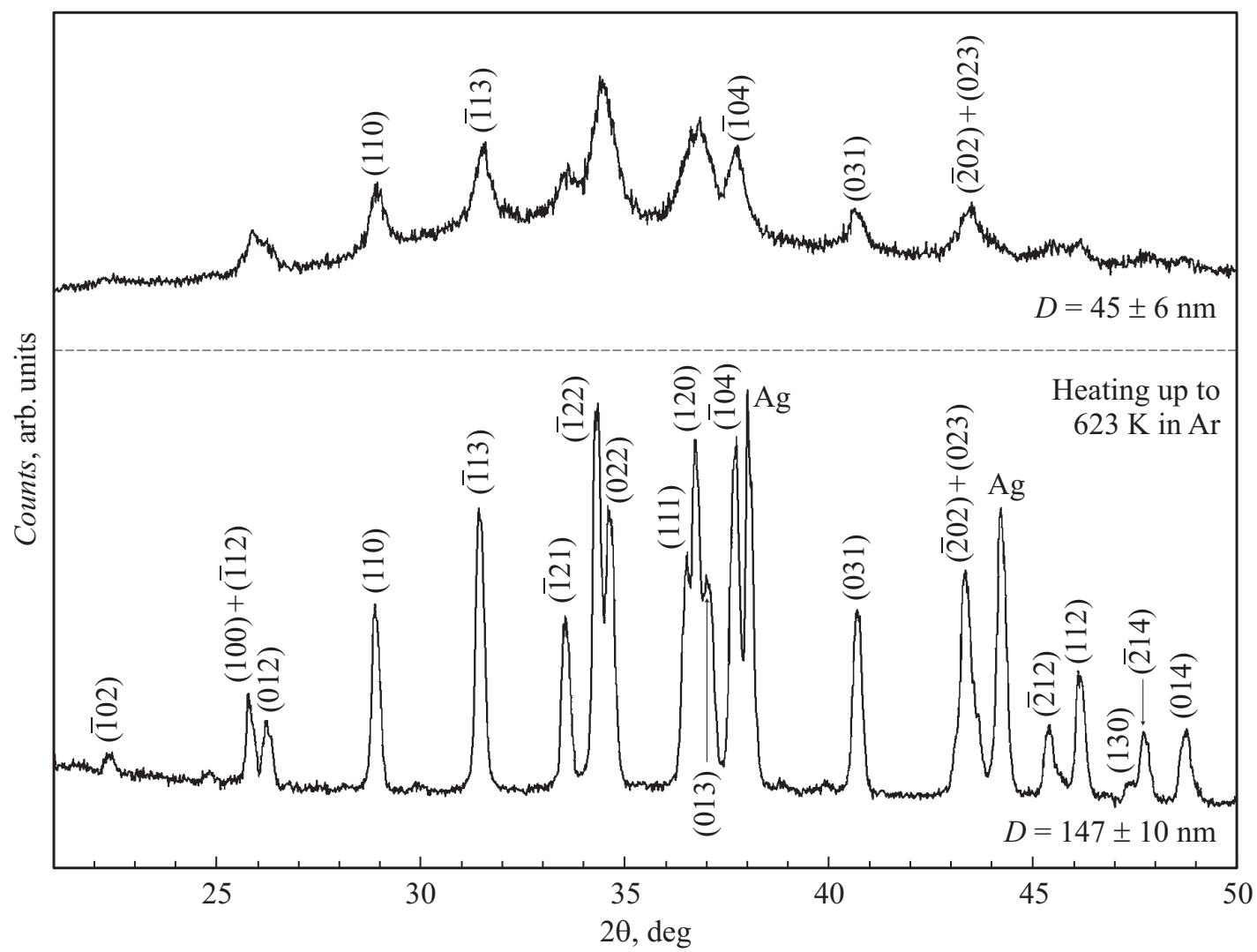

Рис. 1. Рентгенограммы синтезированного нанопорошка сульфида серебра с размером $D$ наночастиц $\sim 45 \mathrm{~nm}$ и того же порошка после нагрева от комнатной температуры до $623 \mathrm{~K}$ в аргоне со скоростью нагрева $10 \mathrm{~K} \cdot \mathrm{min}^{-1}$.

химическим осаждением из растворов нитрата серебpa $\mathrm{AgNO}_{3}$, сульфида натрия $\mathrm{Na}_{2} \mathrm{~S}$ и цитрата натрия $\mathrm{Na}_{3} \mathrm{C}_{6} \mathrm{H}_{5} \mathrm{O}_{7}$ по ранее описанной методике [4].

Кристаллическую структуру синтезированного и отожженных нанопорошков $\mathrm{Ag}_{2} \mathrm{~S}$ исследовали на дифрактометрах Shimadzu XRD-7000 и STADI-P (STOE) в $\mathrm{Cu} K \alpha_{1,2}$-излучении в интервале углов $2 \theta=20-95^{\circ}$ с шагом $\Delta(2 \theta)=0.02^{\circ}$ и временем экспозиции $10 \mathrm{~s}$ в каждой точке. Определение параметров кристаллической решетки и окончательное уточнение структуры синтезированных порошков сульфида серебра проводили с помощью программного пакета X'Pert Plus [10].

In situ исследование влияния отжига на размер наночастиц порошка сульфида серебра в области существования моноклинного акантита $\alpha-\mathrm{Ag}_{2} \mathrm{~S}$ проводили методом высокотемпературной рентгеновской дифракции на дифрактометре X'Pert PRO MPD (Panalytical) с печью Anton Paar HTK-1200 Oven.

Дополнительно нанокристаллический порошок сульфида серебра отжигали в вакууме $0.013 \mathrm{~Pa}$ при темпеpatypax 393, 423, 453 и $493 \mathrm{~K}$ в течение $2 \mathrm{~h}$ с нагревом до $T_{\text {ann }}$ со скоростью не более $1 \mathrm{~K} \cdot \mathrm{min}^{-1}$, а также в аргоне при нагреве до $623 \mathrm{~K}$ в течение $2 \mathrm{~h}$ со скоростью $1 \mathrm{~K} \cdot \min ^{-1}$.

Средний размер $D$ частиц (более точно - средний размер областей когерентного рассеяния (ОКР)) в тон- кодисперсных порошках сульфида серебра оценивали методом рентгеновской дифракции по уширению $\beta(2 \theta)$ дифракционных отражений, используя зависимость приведенного уширения отражений $\beta^{*}(2 \theta)=[\beta(2 \theta) \cos \theta] / \lambda$ от вектора рассеяния $s=(2 \sin \theta) / \lambda$ [9-11]. Дифракционные отражения описывали функцией псевдо-Фойгта.

Микроструктуру и размер частиц $\mathrm{Ag}_{2} \mathrm{~S}$ изучали методом сканирующей электронной микроскопии (СЭМ) на микроскопе JEOL-JSM LA 6390.

Нанокристаллический порошок сульфида серебра изучали также методом дифференциальной сканирующей калориметрии (ДСК) на термоанализаторе STA 449 F3 Jupiter (NETZSCH) в атмосфере аргона $\mathrm{Ar}$ под давлением $1.01 \cdot 10^{5}$ Па при нагреве от 300 до $\sim 773 \mathrm{~K}$.

\section{3. Влияние отжига на размер наночастиц $\mathrm{Ag}_{2} \mathrm{~S}$}

Нагрев нанопорошков сульфида серебра со скоростью $5 \mathrm{~K} \cdot \mathrm{min}^{-1}$ и более в вакууме $0.013 \mathrm{~Pa}\left(10^{-4} \mathrm{~mm} \mathrm{Hg}\right)$ или в атмосфере аргона или гелия при давлении $1.01 \cdot 10^{5} \mathrm{~Pa}$ до температуры $\geq 623 \mathrm{~K}$ сопровождался появлением металлического серебра. На рис. 1 как пример показано изменение рентгенограмм нанопорошка $\mathrm{Ag}_{2} \mathrm{~S}$ после нагрева в атмосфере аргона до $623 \mathrm{~K}$ со скоростью 


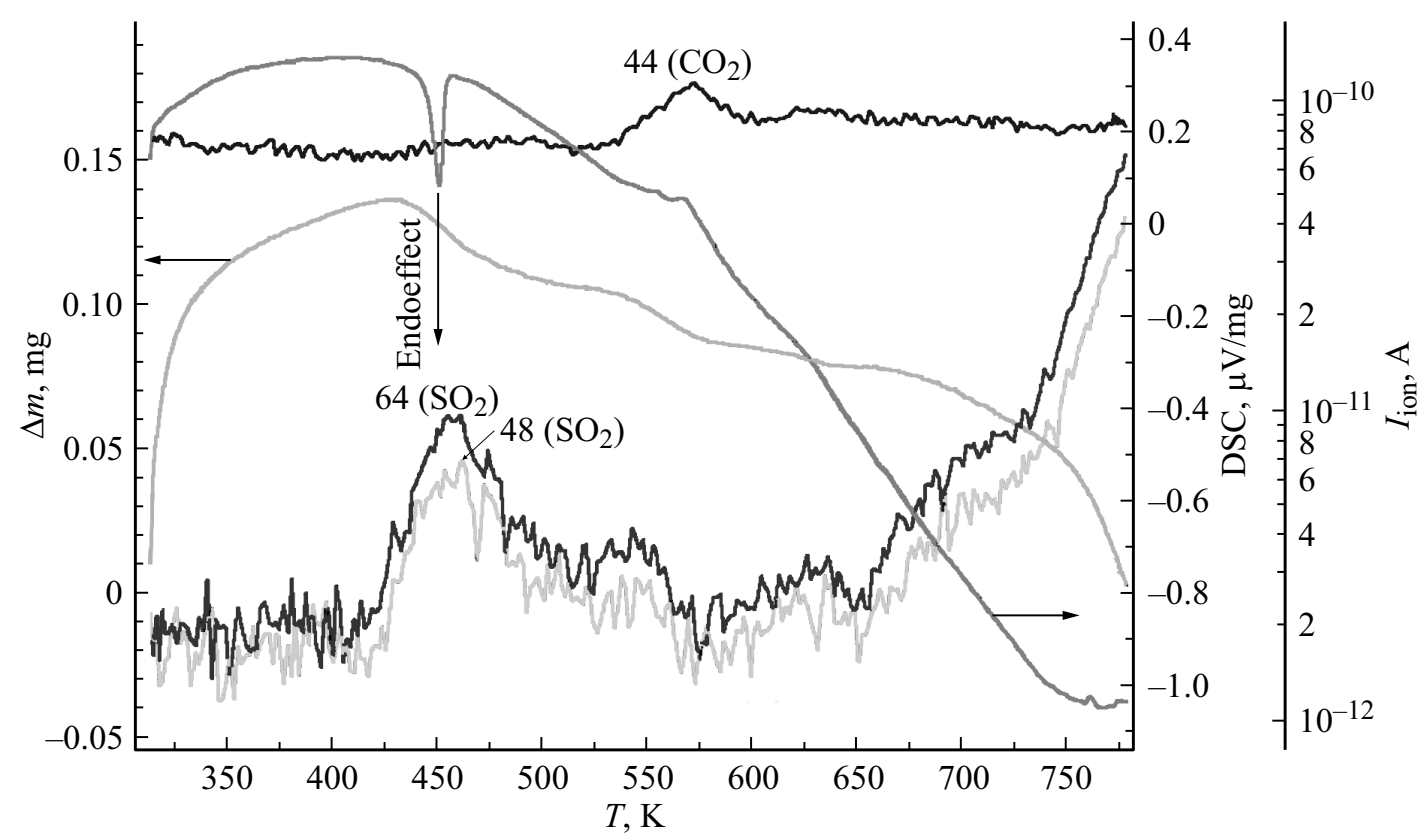

Рис. 2. Потеря массы при нагреве нанопорошка сульфида серебра в атмосфере синтетического воздуха и анализ выделяющихся газов. Максимумы, наблюдаемые на температурных зависимостях ионного тока при $430-510 \mathrm{~K}$ и $570 \mathrm{~K}$, соответствуют выделению $\mathrm{SO}_{2}$ и $\mathrm{CO}_{2}$.
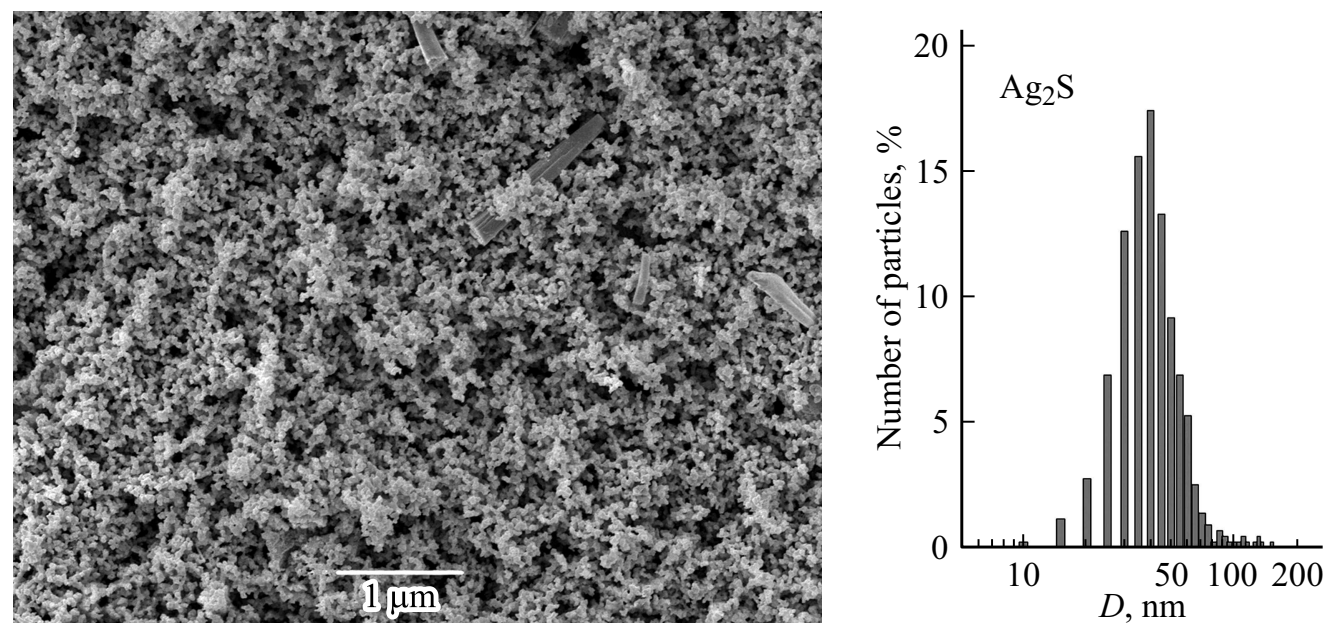

Рис. 3. Электронно-микроскопическое изображение исходного нанопорошка $\mathrm{Ag}_{2} \mathrm{~S}$ и распределение его наночастиц по размеру $D$.

$10 \mathrm{~K} \cdot \mathrm{min}^{-1}$. Согласно дифракционным данным оба порошка $\mathrm{Ag}_{2} \mathrm{~S}$ в качестве основной фазы содержат моноклинный (пр. гр. $P 2_{1} / c$ ) акантит $\alpha-\mathrm{Ag}_{2} \mathrm{~S}$ (рис. 1). Оценки среднего размера $D$ областей когерентного рассеяния нанопорошков были сделаны по уширению не перекрывающихся дифракционных отражений (1 10$),\left(\begin{array}{lll}-1 & 1 & 3\end{array}\right)$, $(-104)$ и (03 1). В результате нагрева размер частиц порошка увеличился от $\sim 45$ до $\sim 147 \mathrm{~nm}$, в порошке появилось около $3.5 \mathrm{wt} \%$ металлического серебра.

Причиной выделения металлического серебра при быстром нагреве нанопорошка сульфида серебра может быть окисление части серы в сульфиде кислородом и влагой, адсорбированными поверхностью нанопорош- ка, удаление серы в виде газообразных оксидов и, вследствие этого, высвобождение некоторого количества серебра.

Дифференциальная сканирующая калориметрия нанопорошка $\mathrm{Ag}_{2} \mathrm{~S}$, совмещенная с термогравиметрическим измерением, обнаружила, что при нагреве нанопорошка до $\sim 800 \mathrm{~K}$ наблюдается потеря массы $\sim 1.0-1.5 \%$ (рис. 2). Для выяснения причин потери массы был проведен специальный эксперимент по нагреву нанопорошка сульфида серебра в атмосфере синтетического воздуха с определением потери массы и параллельным анализом выделяющихся газов на масс-спектрометре, связанном с термоанализатором STA 449 C. 


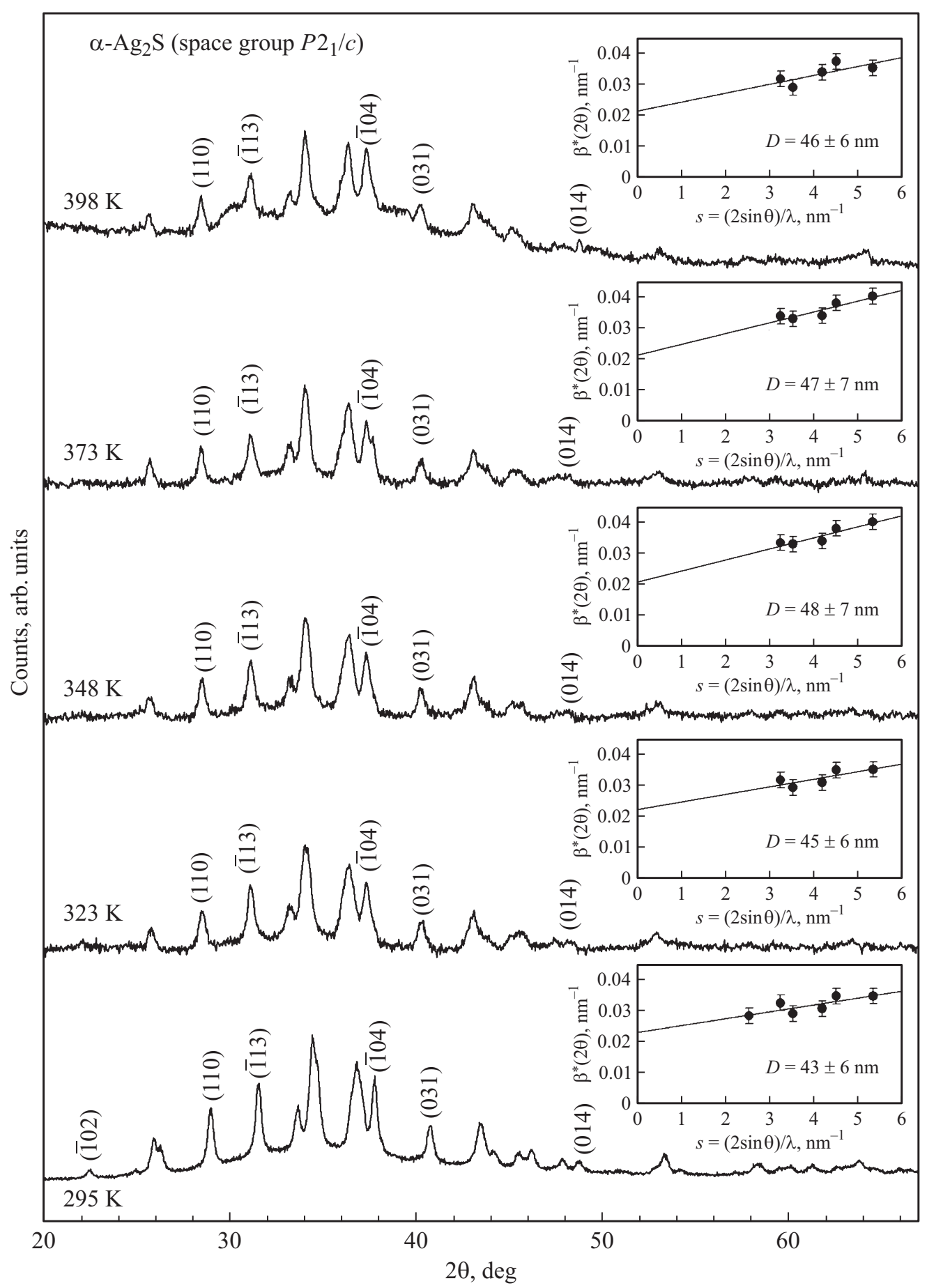

Рис. 4. Рентгенограммы нанокристаллического акантита $\alpha-\mathrm{Ag}_{2} \mathrm{~S}$ при нагреве от 300 до $398 \mathrm{~K}$. На вставках показаны оценки среднего размера областей когерентного рассеяния по уширению неперекрывающихся дифракционных отражений.

Измерения показали, что на температурных зависимо-

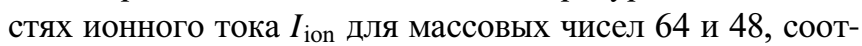
ветствующих $\mathrm{SO}_{2}$ [12], в области температур 430-510 K видны отчетливые максимумы (рис. 2). Можно полагать, что наблюдаемая в этой же температурной области убыль массы $\sim 0.3 \%$ связана с выделением серы и образованием $\mathrm{SO}_{2}$. Активное выделение $\mathrm{SO}_{2}$ происходит также при температуре выше $670 \mathrm{~K}$. Максимум при тем- пературе $\sim 570 \mathrm{~K}$ имеется на температурной зависимости ионного тока для массового числа 44, соответствующего $\mathrm{CO}_{2}$ [12]. Выделение $\mathrm{CO}_{2}$ является следствием окисления углерода. Источниками серы в синтезированных порошках сульфида серебра являются собственно сульфид серебра и примесь исходного реагента $\mathrm{Na}_{2} \mathrm{~S}$, а источником углерода служит примесь другого исходного реагента - цитрата натрия $\mathrm{Na}_{3} \mathrm{C}_{6} \mathrm{H}_{5} \mathrm{O}_{7}$. Водные 
растворы сульфида и цитрата натрия адсорбируются поверхностью нанопорошков $\mathrm{Ag}_{2} \mathrm{~S}$ при их осаждении, и малые количества влаги и этих примесей сохраняются в синтезированных порошках сульфида серебра даже после промывания.

Для того, чтобы избежать при температурных измерениях потери части серы вследствие ее окисления адсорбированными примесями влаги и кислорода и обусловленного этим выделения металлического серебра, нанопорошки сульфида серебра предварительно отжигали в вакууме $0.013 \mathrm{~Pa}\left(10^{-4} \mathrm{~mm} \mathrm{Hg}\right)$. Медленный нагрев в вакууме до температуры отжига $393 \mathrm{~K}$ проводили в течение $2 \mathrm{~h}$ со скоростью $0.5 \mathrm{~K} \cdot \mathrm{min}^{-1}$, затем нанопорошки 2 часа отжигали при температуре $393 \mathrm{~K}$ в вакууме. По данным дифференциального термического анализа при нагреве отожженных нанопорошков сульфида серебра потери массы нет.

Последующее влияние температуры отжига на размер наночастиц изучали на отожженных нанопорошках сульфида серебра.

На рис. 3 показано SEM-изображение исходного нанокристаллического порошка $\mathrm{Ag}_{2} \mathrm{~S}$ и размерное распределение наночастиц в этом порошке. Средний размер наночастиц составляет $\sim 45 \mathrm{~nm}$.

Рентгенограммы нанокристаллического сульфида серебра, зарегистрированные при температурах 295, 323, 348, 373 и $398 \mathrm{~K}$ (рис. 4), содержат одинаковый набор уширенных дифракционных отражений, соответствующих нестехиометрическому моноклинному (пр. гр. $\left.P 2_{1} / c\right)$ акантиту $\alpha-\mathrm{Ag}_{1.93-1.98} \mathrm{~S}$ [4]. Средний размер $D$ областей когерентного рассеяния в исходном нанопорошке равен $43 \pm 6 \mathrm{~nm}$ и согласуется с размером наночастиц по данным сканирующей электронной микроскопии. Последовательный нагрев нанопорошка до $398 \mathrm{~K}$ в пределах ошибок измерений не привел к сколько-нибудь заметному сужению дифракционных отражений, т.е. не сопровождался увеличением размера наночастиц, хотя разрешение дифракционных отражений в области $2 \theta<28^{\circ}$ ослабло. Согласно сделанным оценкам, средний размер ОКР в нанопорошке акантита при температуре $398 \mathrm{~K}$ составляет $46 \pm 6 \mathrm{~nm}$.

Дополнительно нанопорошок сульфида серебра отожгли в вакууме $0.013 \mathrm{~Pa}$ при 393, 423, 453 и $493 \mathrm{~K}$ в течение $2 \mathrm{~h} \mathrm{c}$ нагревом до $T_{\text {ann }}$ со скоростью не более $1 \mathrm{~K} \cdot \mathrm{min}^{-1}$ и в аргоне при $623 \mathrm{~K}$ в течение $2 \mathrm{~h}$ с нагревом со скоростью $1 \mathrm{~K} \cdot \mathrm{min}^{-1}$.

Рентгенограммы нанопорошка сульфида серебра, отожженного при 393, 423, 453 и $493 \mathrm{~K}$ (рис. 5), содержат уширенные дифракционные отражения, соответствующие нестехиометрическому моноклинному (пр. гр. $\left.P 2_{1} / c\right)$ акантиту $\alpha-\mathrm{Ag}_{1.95-1.98} \mathrm{~S}$.

C учетом ошибок оценки размера $D$, двухчасовой отжиг при температуре до $423 \mathrm{~K}$ не привел к росту размера. Слабый рост размера ОКР наблюдается только для нанопорошков, отожженных при 453 и $493 \mathrm{~K}$ (рис. 5). Величина микронапряжений, составляющая в исходном нанопорошке около $0.1 \%$, в результате отжига уменьшилась до $\sim 0.03-0.05 \%$. В нанопорошке, отожженном в аргоне при $623 \mathrm{~K}$ в течение $2 \mathrm{~h}$, размер $D$ частиц составил $147 \pm 10 \mathrm{~nm}$. Размер $D$ частиц в образце, спрессованном из нанопорошка сульфида серебра и отожженном при $930 \mathrm{~K}$, составил $260 \pm 10 \mathrm{~nm}$.

Изменение размера наночастиц $\mathrm{Ag}_{2} \mathrm{~S}$ в зависимости от температуры вакуумного отжига показано на рис. 6. В области $T_{\text {ann }}<440 \mathrm{~K}$ размер наночастиц с увеличением $T_{\text {ann }}$ с учетом ошибок измерений почти не меняется, поэтому интервал температур 273-443 K можно рассматривать как область термической стабильности размера наночастиц $\mathrm{Ag}_{2} \mathrm{~S}$. Это означает, что электронные устройства на основе наноструктурированного сульфида серебра могут стабильно работать в этом интервале температур. Наблюдаемый рост наночастиц происходит при $T_{\text {ann }}>455 \mathrm{~K}$, хотя даже в диапазоне температур 460-930 K частицы сульфида серебра сохраняют наноразмерный масштаб и не достигают микрометрового размера. Диапазон температур 460-930 K, в котором размер частиц начинает заметно расти и увеличивается в 3-6 раз, соответствует области собирательной рекристаллизации нанопорошка сульфида серебра. Заметим, что переход от области термической стабильности размера наночастиц $\mathrm{Ag}_{2} \mathrm{~S}$ к области собирательной рекристаллизации происходит при температуре, близкой к температуре фазового превращения „,акантит $\alpha-\mathrm{Ag}_{2} \mathrm{~S}$-аргентит $\beta-\mathrm{Ag}_{2} \mathrm{~S}$ “, , равной $\sim 450 \mathrm{~K}[13]$.

Изменение среднего размера частиц (зерен) при собирательной рекристаллизации в наноматериалах связано с ее продолжительностью $t$ общим соотношением $D^{n}-D_{0}^{n} \sim t$, где $n=1-4$ [14]. Рост зерен (собирательная рекристаллизация) происходит в результате химической диффузии, когда отсутствует градиент концентраций, но имеется отличный от нуля градиент химического потенциала. Разность химического потенциала между частицами разного размера обусловлена вкладом поверхностной энергии в общую энергию частицы. Относительная величина этого вклада тем больше, чем меньше размер частицы, поэтому при прочих равных условиях мелкие частицы обладают избыточной энергией по сравнению с крупными. Отсюда ясно, что термодинамической причиной самопроизвольного роста частиц в поликристаллическом веществе является понижение общей энергии системы в этом процессе. Согласно [15], если рост частиц обусловлен только понижением общей поверхностной энергии системы вследствие диффузии, то изменение размера частицы $D$ в процессе рекристаллизации описывается выражением

$$
D^{2}-D_{0}^{2}=k t,
$$

где $D_{0}$ - начальный размер частицы (зерна), $t-$ продолжительность отжига, $k$ - коэффициент, экспоненциально зависящий от температуры.

Однако рекристаллизация является более сложным процессом, чем диффузия, и не сводится к последней. Характеристикой собирательной рекристаллизации является энергия активации $Q$. В литературе нет сведений 


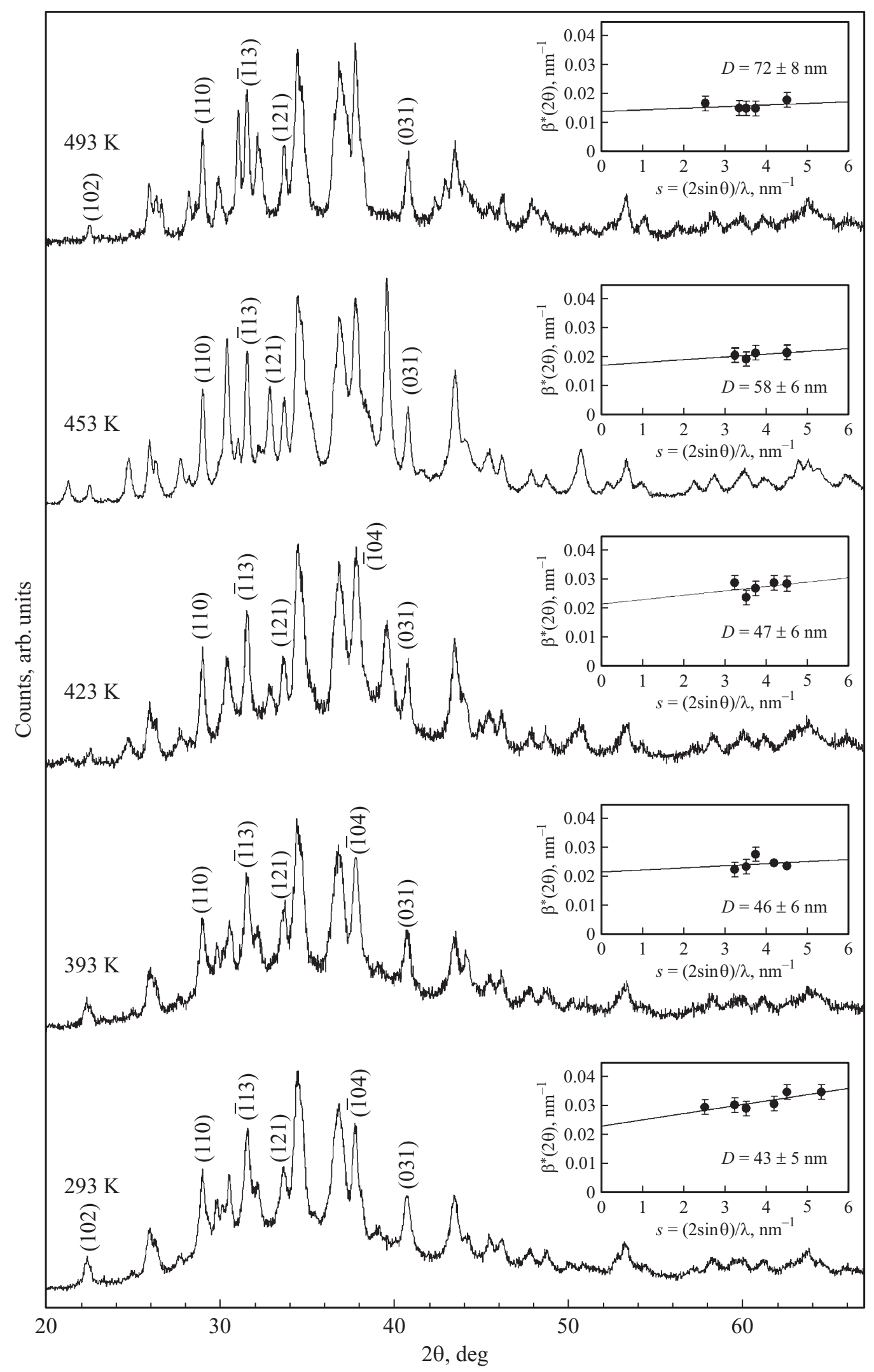

Рис. 5. Рентгенограммы нанопорошка сульфида серебра $\alpha-\mathrm{Ag}_{2} \mathrm{~S}$, отожженного в вакууме при $393,423,453$ и $493 \mathrm{~K}$. Указаны индексы не перекрывающихся дифракционных отражений, по которым оценивали величину уширения. Оценки среднего размера $D$ по уширению этих отражений показаны на вставках. 


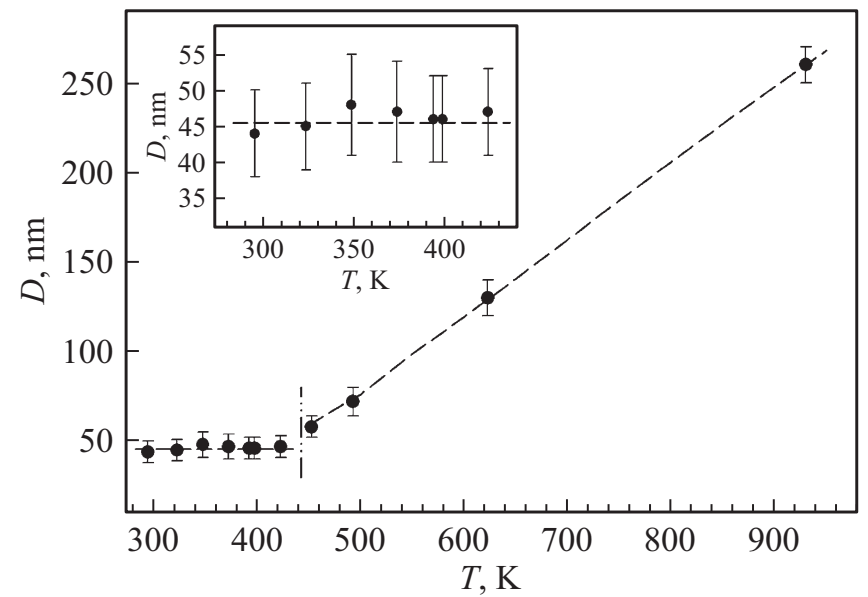

Рис. 6. Влияние температуры отжига на размер $D$ наночастиц порошка $\mathrm{Ag}_{2} \mathrm{~S}$. Вертикальным штрих-пунктиром отмечена верхняя граница области термической стабильности размера наночастиц сульфида серебра. На вставке область термической стабильности показана в увеличенном масштабе.

об энергии активации собирательной рекристаллизации в сульфидах, особенно в нанокристаллических. В работе [16] на примере диоксида урана и в работе [17] на примере нитрида алюминия, борида титана и других наноструктурированных веществ и материалов было показано, что изменение размера зерна $D$ в процессе собирательной рекристаллизации описывается выражением

$$
D^{3}-D_{0}^{3}=k_{0} t \exp (-Q / R T),
$$

где $k_{0}-$ нормирующий коэффициент. При одинаковой продолжительности $t$ отжига выражение (2) можно записать как

$$
D^{3}-D_{0}^{3}=k_{t=\text { const }} \exp (-Q / R T) .
$$

Из (3) следует, что при прочих равных условиях размер частицы будет тем меньше, чем больше энергия активации.

Данные по зависимости размера $D$ наночастиц сульфида серебра от температуры отжига, представленные на рис. 6, в первом приближении можно описать функцией (3). В соответствии с экспериментальными данными величина $D_{0}$ была принята равной $45 \mathrm{~nm}$. Количественная минимизация зависимости $D(T)$ функцией (3) с учетом $D_{0}=45 \mathrm{~nm}$ показала, что для наноструктурированного сульфида серебра в области температур $450-900 \mathrm{~K}$ энергия активации $Q$ собирательной рекристаллизации равна $\sim 33.6 \mathrm{~kJ} \cdot \mathrm{mol}^{-1}(\sim 0.35 \mathrm{eV}$ на формульную единицу $\mathrm{Ag}_{2} \mathrm{~S}$ или $\sim 0.12 \mathrm{eV} \cdot$ atom $^{-1}$ ).

Нужно отметить, что термическая стабильность размера наночастиц $\mathrm{Ag}_{2} \mathrm{~S}$ меньше, чем наночастиц сульфида свинца $\mathrm{PbS}$ [2]. Для сульфида серебра $\mathrm{Ag}_{2} \mathrm{~S}$ рост наночастиц начинается при температуре $\sim 460 \mathrm{~K}$, тогда как наночастицы сульфида свинца $\mathrm{PbS}$ начинают расти при температуре $\sim 700 \mathrm{~K}$. По-видимому, меньшая область термической стабильности размера наночастиц $\mathrm{Ag}_{2} \mathrm{~S}$ обусловлена меньшей температурой плавления сульфида серебра $\left(T_{\text {melt }}\right.$ для крупнозернистых $\mathrm{Ag}_{2} \mathrm{~S}$ и $\mathrm{PbS}$ равна 1115 и $1391 \mathrm{~K}$ соответственно). Другой причиной меньшей термической стабильности наночастиц $\mathrm{Ag}_{2} \mathrm{~S}$ может быть наличие в сульфиде серебра фазового превращения при $\sim 450 \mathrm{~K}$; в сульфиде свинца полиморфных фазовых превращений нет.

\section{4. Заключение}

Изучение влияния температуры вакуумного отжига на размер частиц нанопорошков сульфида серебра показало, что увеличение температуры вплоть до $\sim 450 \mathrm{~K}$ приводит к незначительному росту наночастиц и отжигу микронапряжений, что позволяет считать этот диапазон температур областью термической стабильности нанокристаллического порошка сульфида серебра. Благодаря термической стабильности размера наночастиц электронные устройства на основе наноструктурированного сульфида серебра могут стабильно работать в этом интервале температур. Диапазон температур от 450 до $900 \mathrm{~K}$, где размер частиц увеличивается в $3-6$ раз, соответствует температуре собирательной рекристаллизации нанопорошка сульфида серебра.

Исследование выполнено при финансовой поддержке Российского научного фонда (проект № 14-23-00025) в ИХТТ УрО РАН.

\section{Список литературы}

[1] W. Kahle, H. Berger. Phys. Status Solidi A 2, 4, 717 (1970).

[2] С.И. Садовников, Н.С. Кожевникова, А.А. Ремпель. Неорган. материалы 47, 8, 929 (2011).

[3] S.I. Sadovnikov, A.A. Rempel, A.I. Gusev. Russ. Chem. Rev. 87, 4, 303 (2018).

[4] S.I. Sadovnikov, A.A. Rempel, A.I. Gusev. Nanostructured Lead, Cadmium and Silver Sulfides: Structure, Nonstoichiometry and Properties. Springer Int. Publ. AG, Cham-Heidelberg (2018). $331 \mathrm{p}$.

[5] C. Cui, X. Li, J. Liu, Y. Hou, Y. Zhao, G. Zhong. Nanoscale Res. Lett. 10, 431 (2015).

[6] J. Yang, J.Y. Ying. Angew. Chem. Int. Ed. 50, 20, 4637 (2011).

[7] Z. Xu, Y. Bando, W. Wang, X. Bai, D. Golberg. ACS Nano. 4, 5, 2515 (2010).

[8] D. Wang, L. Liu, Y. Kim, X. Huang, D. Pantel, D. Hesse, M. Alexe. Appl Phys Lett. 98, 24, 243109 (2011).

[9] M. Basu, R. Nazir, C. Mahala, P. Fageria, S. Chaudhary, S. Gangopadhyay, S. Pande. Langmuir 33, 13, 3178 (2017).

[10] X'Pert Plus Version 1.0. Program for Crystallography and Rietveld analysis Philips Analytical B. V. (C) Koninklijke Philips Electronics N. V. 
[11] A.I. Gusev, A.A. Rempel. Nanocrystalline Materials. Cambridge Int. Science Publ. Cambridge (2004). 351 pp.

[12] NIST Chemistry WebBook, NIST Standard Reference Database Number 69 / Eds Linstrom P.J., Mallard W.G. (2005).

[13] С.И. Садовников, А.И. Гусев. ФТТ 59, 9, 1863 (2017).

[14] Словарь нанотехнологических и связанных с нанотехнологиями терминов / Под ред. С.В. Калюжного. Физматлит, M. (2010). 527 c.

[15] А.К. Федотов. Физическое материаловедение. Фазовые превращения в металлах и сплавах. Выш. шк., Минск (2012). $446 \mathrm{c}$.

[16] F.A. Nichols. J. Appl. Phys. 37, 4599 (1966).

[17] Functional Gradient Materials and Surface Layers Prepared by Fine Particles Technology / Eds M.-I. Baraton, I.V. Uvarova. Dorfrecht: Kluwer (2001). 317 pp.

\section{Редактор Т.Н. Василевская}

